\title{
RESEARCH IN CHARITY ACCOUNTING AND REPORTING: A FERTILE FIELD FOR EXPLORATION
}

\author{
Ciaran Connolly, Noel Hyndman and Danielle McConville \\ Queen's University Belfast
}

\begin{abstract}
lthough the charity sectors in the United Kingdom (UK) and the Republic A of Ireland (RoI) are both substantial in numerical terms and in economic impact, research in the area by accounting and finance academics is limited. Substantial challenges in terms of accounting, accountability and governance are faced by the sectors as they strive to engage with their stakeholders in meaningful ways. This paper explores some key themes of research in this area that have been central to the authors' interests over many years and, on the basis of this, and on wider reflection as to the operation and importance of the charity sector in both the UK and the RoI, highlight potentially fruitful future research for accounting and finance academics.
\end{abstract}

\section{INTRODUCTION}

The not-for-profit (NFP) sector, which is also referred to as the third sector or the voluntary sector, represents the sphere of social activity undertaken by organisations that are non-profit and non-governmental. ${ }^{1}$ The NFP sector is quite different from either the private or the public sector in terms of its orientation and motivation, the nature of its activities, its resource availability to engage in these activities and the manner of its contribution to the public good. Some charitable organisations in the United Kingdom (UK) and Republic of Ireland (RoI) ${ }^{2}$ are substantial international organisations while others are small locally based groups run by volunteers. Regardless of their size, charities play a significant and vital role in society, often serving and helping those who are most disadvantaged, marginalised or helpless, and increasingly delivering public services to tackle social exclusion. 
As a result, they make a unique and widely recognised contribution to the public good by building social capital in civil society. However, the rise in the visibility and influence of the charity sector in recent years, together with adverse publicity surrounding a number of high-profile scandals of fund misappropriation and organisational inefficiency (Brody, 2002; Beattie, McInnes and Fearnley, 2002; Home Office, 2003; Charity Commission, 2004), has highlighted the need for an increased focus on charity accountability and good governance. This could be seen as a basis for ensuring greater confidence in the control processes within charities (which may encourage greater willingness on the part of donors to provide funding), as well as providing further legitimisation of the sector's activities. These conditions can be seen as crucial to ensuring the health and growth of the sector.

Although the charity sectors in the UK and the RoI are both substantial in numerical terms and in economic impact, research in the area by accounting and finance academics in Ireland and elsewhere is limited. Substantial challenges in terms of accounting, accountability and governance are faced by the sectors as they strive to engage with their stakeholders in meaningful ways. The objectives of this paper are to explore some key themes of research in this area that have been central to the authors' interests over many years, and, on the basis of this, to highlight potentially fruitful future research for accounting and finance academics in Ireland and elsewhere. It seeks to present past research and excite academics who have not previously considered the potential for research in this field. The remainder of the paper proceeds as follows. The next section briefly profiles the charity sectors in the UK and the RoI as a basis for understanding context. This is followed by an analysis of governance, accounting and accountability, and then an examination of the drivers of charity accountability in the UK and the RoI. Some key research themes, including output from the authors, over the last thirty years relating to charity accounting, accountability and governance is subsequently presented. The paper concludes with the identification of possible areas for future research.

\section{THE CHARITY SECTOR IN THE UNITED KINGDOM AND REPUBLIC OF IRELAND}

The charity sector in the UK and the RoI is a vast and growing segment of economic activity. There are approximately 162,000 charities in England and Wales with an estimated total annual income of $£ 56$ billion, a $£ 4$ billion increase from 2010 (Charity Commission, 2011). In addition, there are over 23,000 charities in Scotland and 4,700 such organisations in Northern Ireland (NI) with total estimated annual incomes of approximately $£ 8$ billion and $£ 570$ million respectively (Charity Commission for Northern Ireland, 2011; Northern Ireland Council for Voluntary Action, 2009; Office of the Scottish Charity Regulator, 2011). It is estimated that there are approximately 5,700 charities operating in the RoI, collecting more than $€ 500$ million annually in donations (Irish Times, 2011).

While the charity sector in the UK and the RoI is growing, the income distribution is skewed with a small number of large charities accounting for a significant proportion of the total sector income. For example, in England and Wales 833 large 
charities (just over one-half of 1 per cent of total charities) account for 56 per cent of total income (Charity Commission, 2011). The sector's growth has led to increased visibility and scrutiny by diverse stakeholders including government, funders, the media and the public. Moreover, as charities in the UK and the RoI operate under different legal structures, coupled with the difficulties in defining the sector and the fact that different systems of charity administration exist in England and Wales, NI, the RoI and Scotland, the resulting complexity has immense implications for the development of clear principles of accountability (this is discussed further below).

The UK charity sector employs over 600,000 people, up 25 per cent over the last decade, and the public is increasingly engaged in voluntary activities, with 45 per cent of the public volunteering at least once a year and 29 per cent at least once a month (National Council for Voluntary Organisations and Charities Aid Foundation, 2010). While there is a growing reliance on earned income (50 per cent of total income) within the sector, voluntary income continues to play a significant role (40 per cent), with the remaining 10 per cent largely consisting of dividend and interest income (Cabinet Office of the Third Sector, 2009). Individuals and government are important sources of income for the sector, contributing 37 per cent and 34 per cent respectively of the total income in the UK. Albeit on a smaller scale, evidence indicates that the RoI charity landscape exhibits similar features to that of the UK (Donoghue, O'Regan, McGee and Donovan, 2007). Consequently, since a considerable amount of charitable work is supported by the general public - either as direct givers through donations and/or through voluntary activities, or as indirect givers through taxes - it is critical that there are appropriate systems in place, not only to ensure that public money is not misappropriated and is fittingly and effectively spent for the communities the funds were intended for, but also to sustain the health and longevity of both the sector and the groups and communities that charities seek to serve.

\section{CHARITY GOVERNANCE, ACCOUNTING AND ACCOUNTABILITY}

Good governance is a leitmotif in discussions on how organisations should operate. In the business sector one of the seminal contributions to the UK debate on corporate governance, the Cadbury Report (1992, para. 2.5), states that 'corporate governance concerns the way in which companies are directed and controlled'. Often concepts of governance as applied in the business sector literature are considered in relation to principal-agent theory, with the focus primarily being concerned with how suppliers of finance protect, and get a return from, their investments (a clear issue in the recent systemic banking crisis). Basically, individuals are assumed to be rational utility maximisers, meaning they will improve their own welfare, potentially at the expense of others, if it is possible to do so. Corporate governance may be viewed as the way in which shareholders (viewed as the dominant stakeholder) compel managers to act in their best interests (thereby maximising shareholders' wealth) or, indeed, how managers convince shareholders that they are doing so.

Immediately, it is apparent that this definition is inappropriate for use in a charity. The most fundamental problem is that charities are not supposed to 
provide a financial return to their fund providers. Rather, suppliers of funds generally want the charity to use the money to benefit other individuals or groups of individuals (beneficiaries). Donors may have an interest in maximising the pass-through ratio, which is the fraction of a charity's revenues that is ultimately distributed to beneficiaries, in the same way that shareholders have an interest in maximising the net cash flows of the company they invest in. One element of governance in charities may therefore be the way in which either donors compel (or, perhaps more fittingly in the charity sector, encourage and support) the trustees and workers (whether employed or volunteers) to distribute as much as possible to the intended beneficiaries (and achieve the greatest impact for the money distributed) or a charity's trustees and staff convince (potential) donors that that is what they will do.

Principal-agent theory might also suggest that one would expect to see some degree of monitoring of charities by donors (and possibly beneficiaries) and regulators (who, partially at least, are assumed to act in the interest of donors - an issue explored in Hind, 2011). Additionally, principal-agent theory can also be applied within a charity. For example, the board of trustees may steer (or monitor) the highest-paid staff of a charity, who themselves may steer (or monitor) those situated lower in the organisational hierarchy (including volunteers). In the UK, the voluntary sector's own governance code, Good Governance: A Code for the Voluntary and Community Sector (Governance Code Steering Group, 2010), although highlighting many principles of governance present in corporate models, is tailored to the circumstances in which charities operate - where, for example, objectives are other than to make money and motivations for involvement may be heavily influenced by altruism. In the voluntary sector code, integrity is added to the skills set expected from a charity's trustee board and the fundamental nature of charity is emphasised with the reminder that trustees 'lead in setting and championing the values and ethos of the organisation' (Governance Code Steering Group, 2010, p. 20) and the 'board should always ... make decisions in the best interests of the people or cause it aims to help' (Governance Code Steering Group, 2010, p. 14).

While the concept of what is meant by 'governance' is rather fuzzy and a myriad of ideas are often placed under the umbrella of 'good governance', themes that often emerge relate to good accounting and comprehensive accountability. The conventional view of accounting is that it is a purposive activity, directed towards a specified end - that is, the meeting of users' information needs (American Accounting Association, 1966; Canadian Institute of Chartered Accountants, 1980; Macve, 1981; Accounting Standards Board, 1999). While the main focus of these publications was on corporate accounting issues, they helped stimulate debate on users' needs with respect to the charity sector. The user-needs emphasis was evident in the Trueblood Report (American Institute of Certified Public Accountants, 1973) and the Statement of Financial Accounting Concepts No. 4, Objectives of Financial Reporting by Non-Business Organizations (Financial Accounting Standards Board, 1980), in the United States, and in the work of Bird and Morgan-Jones (1981) in the UK. Indeed, this latter research ultimately led to the publication of Statement of Recommended Practice (SORP) 2, Accounting by Charities (Accounting Standards Committee, 1988), ${ }^{3}$ which, together with subsequent revisions, sought to reduce the 
diversity of accounting practice in charities' published financial statements on the basis that a lack of consistency makes it difficult for users of accounts to understand (and therefore use) the information provided.

Before considering accountability in the context of charities specifically, it is important to note that despite being a much-debated topic in the literature, the concept remains an abstract construct that lacks a clear definition (Munro and Mouritsen, 1996; Ebrahim, 2003; Geer, Maher and Cole, 2008). Various conceptualisations and measures of the construct are offered in the literature (Roberts, 1991; Sinclair, 1995), and the concept has been studied from different perspectives and in different contexts. For example, previous research has considered accountability in the context of principal-agent theory (Laughlin, 1990; Edwards and Hulme, 1995), stakeholder theory (Gray, Kouhy and Lavers, 1995; Mäkelä and Näsi, 2010) and legitimacy theory (Deegan, 2002; Campbell, Moore and Shrives, 2006; Tilling and Tilt, 2010). The concept has also been examined in terms of the role and value of the different mechanisms of accountability (O'Dwyer, 2005; O'Dwyer and Unerman, 2007), the play-out of accountability in organisations (Panozzo, 1996; Ezzamel, Robson, Stapleton and McLean, 2007) and the discharge of accountability through public discourse (Connolly and Dhanani, 2009; Dhanani, 2009).

Jackson (1982) and the Government Accounting Standards Board (1987) describe accountability as being responsible to someone or for some event and as explaining one's actions and justifying what has been done respectively. Rutherford (1983) views accountability as being related to the requirement to be answerable for one's conduct and responsibilities. In contrast, Goodin (2003), Brody (2002) and Taylor and Rosair (2000) identify and distinguish between different themes or states of affairs for which one may be responsible and may in turn (be made to) account for. Goodin's (2003) states of affairs include one's intentions, which for charities translate into the missions, visions and objectives that the organisations are working towards; one's actions, that is, the actual activities and programmes undertaken by charities to fulfil their visions and objectives; and one's results, that is the extent to which the organisations have achieved their mission and objectives.

Brody (2002) and Taylor and Rosair (2000), who classify Goodin's themes as managerial accountability, add that charities also need to discharge fiduciary accountability whereby appropriate systems and measures such as good compliance, control and governance practices are in place to ensure financial probity. Fiduciary accountability emphasises probity, compliance, control and good governance to assure organisational stakeholders that the funds, assets and future of the organisation are safeguarded (Taylor and Rosair, 2000; Brody, 2002). In this regard, it is analogous to the stewardship function that financial accounting fulfils, whereby there is confirmation and, in turn, confidence that the funds and assets of the organisation are not being misappropriated. Managerial accountability (Goodin's themes), on the other hand, refers to managerial effectiveness and the impact of the organisation on society (i.e. organisational success). Based on the notion that charities should provide a review of their financial position and the impact that they have had on societal development, managerial accountability can be further separated into managerial success in financial terms and in non-financial, operational/societal terms as follows: 
- Financial managerial accountability looks at managerial success in relation to generating funds and using them appropriately to secure the future of the organisation and to optimise its impact.

- Non-financial, operational accountability measures the organisation's impact in relation to the charitable objects for which it was set up.

Thus, charity accountability may be categorised as fiduciary accountability, financial managerial accountability and operational managerial accountability (see Table 1).

\section{TABLE I: ACCOUNTABILITYTHEMES AND ASSOCIATED DISCLOSURES}

\begin{tabular}{|c|c|}
\hline Themes of Accountability & Associated Disclosure Items \\
\hline $\begin{array}{l}\text { Fiduciary accountability emphasises probity, } \\
\text { compliance, control and good governance, to } \\
\text { assure organisational stakeholders that the } \\
\text { funds, assets and future of the organisation are } \\
\text { safeguarded }\end{array}$ & $\begin{array}{l}\text { - Organisation structure, including managerial } \\
\text { structures and how key decisions are made } \\
\text { - Trustee selection, appointment induction } \\
\text { and training policies } \\
\text { - Reserves policy } \\
\text { - Financial investment policy } \\
\text { - Risk management statement }\end{array}$ \\
\hline $\begin{array}{l}\text { Financial managerial accountability addresses } \\
\text { organisational performance in financial terms, } \\
\text { that is, managerial success at generating } \\
\text { and using funds. To enhance performance } \\
\text { accountability, information dimensions include: } \\
\text { - Comparison of actual performance with } \\
\text { targets } \\
\text { - Objectives, previous year results or } \\
\text { competitor organisations } \\
\text { - Explanations/justifications for activities and } \\
\text { Performance }\end{array}$ & $\begin{array}{l}\text { - Financial position/stability (income, } \\
\text { expenditure and surplus/deficit levels) } \\
\text { - Financial performance of investments and } \\
\text { reserves policies } \\
\text { - Fundraising efficiency } \\
\text { - Overall organisational efficiency }\end{array}$ \\
\hline $\begin{array}{l}\text { Operational managerial accountability } \\
\text { addresses performance in terms of the impact } \\
\text { of the organisation on society; to enhance } \\
\text { performance accountability, information similar } \\
\text { to that stated above applies }\end{array}$ & $\begin{array}{l}\text { - Organisational aims and objectives } \\
\text { - Organisational activities } \\
\text { - Direct charitable activities (inputs, with } \\
\text { separate attention to volunteers, outputs, } \\
\text { results, efficiency and effectiveness) }\end{array}$ \\
\hline
\end{tabular}

While the definitions of accountability presented above contain useful elements, discussions on accountability, particularly in the charity sector, are fraught with problems. The Government Accounting Standards Board (1987) and Patton (1992) suggest that accountability suffers from imprecise meaning, and Rutherford (1983) and Taylor (1989) argue that user-needs models do not explain clearly the information that should be provided. Edwards and Hulme (1995) highlight the problem of multiple accountabilities, suggesting that difficulties in prioritising and reconciling varied user needs may lead to weak accountability. However, regardless of these difficulties, accountability is a key mechanism through which charities can 
achieve legitimacy for their activities and the sector as a whole. Accounting information is central to the discharge of accountability and gives a visibility to the resources, activities and achievements of an organisation, thus enabling informed discussions and decisions that impact on economic well-being. Decisions to give, Walker, Pharoah, Jas, Paasey and Romney-Alexander (2002) opine, are not only about values or faith, but are a result of a variety of factors, one of which is good charity communications. Moreover, the need to discharge accountability arguably supports principal-agent theory since it encourages management to concentrate on issues that are important to stakeholders outside the immediate management of the organisation, who often provide the resources for the organisation to function. Whilst accepting the argument made by Jones and Pendlebury (2010), that accountability, in its widest sense, is more than accounting (however widely accounting is defined), focusing on the information needs of users seems clearly linked with ideas relating to accountability (a key aspect of a contemporary definition of accounting).

By relaying to funders and financial supporters (upward stakeholders), both small and large, the financial probity and efficiency with which they operate and the impact they have on those they serve, charities can gain legitimacy from such parties (Slim, 2002; Ebrahim, 2003; Accounting Standards Board, 2007). Theoretically, it can be argued that their altruistic motive avoids the need for charities to account because, by acting for the public good, they can be assumed to operate honestly and optimally to maximise organisational impact. In practice, however, this assumption may not necessarily hold, and the demands of accountability become validated. Charity funds are being placed under increasing scrutiny and the need to account and to reinstate and maintain public trust and confidence, either voluntarily or on demand, is being increasingly emphasised (Beattie et al., 2002; Ebrahim, 2003; Home Office, 2003). Charity supporters and funders are akin to shareholders of commercial organisations (Accounting Standards Board, 2007), and, while they are arguably less likely to monitor charities as closely as shareholders may commercial organisations, they are more likely to terminate their support if their trust and confidence wane as their personal welfare is not necessarily dependent upon this support. Accountability and transparency are therefore critical attributes with which to gain and maintain public/funder support and trust.

The discharge of accountability also enables charities to achieve legitimacy from their downward stakeholders (i.e. the beneficiary groups and clients). There is a clear disparity in the position of power between the charities and their downward stakeholders (as compared to the situation with upward stakeholders). However, it could be argued that this power should not be exercised to avoid accounting to these stakeholder groups, but rather, recognising their position of weakness, charities, as value-driven organisations, should choose to account to/take account of them. Accounting to and for downward stakeholders enables charities to develop intangible sources of legitimacy such as credibility, reputation, trust and integrity, which will in turn engender the trust and support of their beneficiaries (Slim, 2002). In other words, consistent with the notion of a broader accountability paradigm (vis-á-vis the narrower stewardship and decision usefulness paradigms) (Coy, Fischer and Gordon, 2001), charities have an 'upward' accountability to their funders 
and financial supporters, government and oversight agencies and the public at large, and also a 'downward' accountability to the beneficiary groups and clients who use their services.

As a subsidiary benefit, systems that enable charities to account to their stakeholders also have the potential to facilitate an improvement in organisational performance and learning (Brown and Moore, 2001; Blagescu, Lloyd, Dombrowski, Kadosh and Oatham, 2006). An organisation that is answerable for its actions should be more compelled to improve its performance to demonstrate sound organisational activity and organisational success than one with weak accountability (where there may be a limited incentive to manage the organisation's funds efficiently and effectively) (Hyndman and Anderson, 1995). In relation to organisational learning, Brown and Moore (2001) suggest that organisational successes and (perhaps more so) failures offer extensive learning opportunities upon which to develop, and that sound information is essential to facilitate the learning process. Accountability systems that methodically measure success and failure and produce the relevant information are therefore central to organisational learning.

While acknowledging the many avenues through which organisations (forprofit and NFP) can communicate with their stakeholders, the annual report ${ }^{4}$ is recognised as 'the primary means with which the management of an entity is able to fulfil its reporting responsibility' (Accounting Standards Committee, 1975, p. 16) to discharge its duty of accountability and stewardship (Charity Commission, 2000). Within the public discourse system employed by both for-profit and NFP organisations, the annual report occupies a prominent place as a textually mediated mass communication medium. As a statutory document in most Western economies (Gray, Bebbington and Collison, 2006), it attracts a degree of authenticity not associated with other such media and has become the principal means through which management fulfil their reporting responsibilities (Boyne and Law, 1991; Coy et al., 2001). Presently, the annual report is the communication lens through which stakeholders can understand and monitor organisations' activities, operations, successes and failures. Consequently, it is recognised as one of the most widely used tools with which organisations can account to their stakeholders (Davison, 2007; Samkin and Schneider, 2010). In the context of charities (as noted above), the Accounting Standards Committee developed SORP 2 (Accounting Standards Committee, 1988), which sought to reduce diversity in charity financial statements to aid reader analysis. Subsequent revisions, particularly the 2000 SORP, shifted attention from the presentation of financial statements to the content of narrative information in recognition of its significance in discharging accountability, particularly in the context of charities (Charity Commission, 2000).

\section{DRIVERS OF CHARITY ACCOUNTABILITY IN THE UNITED KINGDOM AND REPUBLIC OF IRELAND}

As much charitable work is supported by public donations, it is important that appropriate safeguards are in place to ensure that such contributions are spent appropriately, and that the organisations effectively serve those for whom the 
funds were intended. Moreover, the manner and strength of charity regulation is arguably a barometer for the way in which charities are valued and viewed in a particular jurisdiction, including the benefits that charitable recognition and status potentially bring.

In the UK and the RoI there are four charity regulators: the Charity Commission for England and Wales, the Charity Commission for Northern Ireland and the Office of the Scottish Charity Regulator in the UK, and the Charities Regulation Unit (Department of Justice and Equality) in the RoI. Although the UK and the RoI comprise four separate legal jurisdictions, they share a common history of charity law dating back to the 1601 Statute of Charitable Uses. Of the four regulators, the Charity Commission for England and Wales is the longest established (founded in 1853), with the others at different stages of their development (for example, the Charity Commission for Northern Ireland was created in 2008 and has yet to begin to register charities (as of November 2011) and often draws on the experiences and practices of the Charity Commission for England and Wales when formulating its policies and procedures).

In recent years, all four jurisdictions have embarked on major changes to their respective regulatory regimes for charities (Breen, Ford and Morgan, 2009), with the Charities Act 2006 (for England and Wales), the Charities Act (Northern Ireland) 2008, the Charities and Trustee Investment (Scotland) Act 2005 and the Irish Charities Act 2009 (for the RoI). While these four pieces of legislation have much in common with respect to their definition of 'charity', and the accounting and registration requirements, there are differences which could potentially cause problems (Breen et al., 2009), for example with respect to cross-border registration, accounting obligations and service provision.

In a UK context, there has been a number of recent initiatives, both regulatory and voluntary, to encourage and promote charity accountability. Recent drivers include the publication of Private Action, Public Benefit: A Review of Charities and the Wider Not-for-Profit Sector (Strategy Unit, 2002), which called for the sector to develop greater accountability and transparency to build public trust and confidence, and Charities and Not for Profits: A Modern Legal Framework - The Government's Response to 'Private Action, Public Benefit' (Home Office, 2003). Subsequent developments include the:

- Publication of the Charity Finance Directors' Group (2003) report Inputs Matter, which seeks to improve charitable transparency through financial reporting and also recommends that a voluntary code of practice be agreed in relation to the content of annual reviews

- Publication of the 2005 SORP (Charity Commission, 2005), which places greater emphasis on the trustees' annual report, promotes the importance of narrative information as part of the annual report and provides detailed and systematic guidance on how this can be achieved

- Publication/revision of charity legislation and establishment/strengthening of regulatory bodies to oversee, promote and encourage accountability within the sector (see above) 
- Introduction of Summary Information Returns in 2005 for larger charities in England and Wales as part their annual return to the Charity Commission, in order to provide the public with easy access to relevant, useful and comparable information about charities

In terms of self-regulation, UK developments and practices aimed at promoting charity accountability include the:

- Establishment of a voluntary code of conduct by the National Council for Voluntary Organisations (2005), the ImpACT (Improving Accountability, Clarity and Transparency) Coalition, to encourage members to enhance the sector's transparency and accountability practices and, in turn, improve public confidence and trust

- Development of a voluntary code of fundraising practice by the Institute of Fundraising (2006) to promote the highest standards in UK fundraising activities (following negative media publicity in this area)

- Creation of databases such as GuideStar (UK) and organisations such as Intelligent Giving (UK) and New Philanthropy Capital (UK) which aim to raise public interest in charitable giving, direct more funding to effective charities and help donors make more informed decisions on how to give. Such organisations attempt to open up and rationalise giving behaviour, especially with government looking to encourage larger tax-effective donations. They are akin to an equity research firm for the NFP sector, analysing the workings of charities and disseminating relevant accountability information to external stakeholders via the internet.

- Joint sponsorship, by the Institute of Chartered Accountants in England and Wales and Charities Aid Foundation, of awards in relation to reporting practices in the charity sector

With respect to the RoI, the Irish Charities Act 2009 favours a non-statutory code of practice, combined with legislation that requires formal registration, collection permits and financial accountability. The Act provides for the appointment of a charities regulation authority to oversee and enforce its provisions, and a charities appeals tribunal to deal with complaints. However, as a result of the economic crisis and the subsequent resource constraints, the RoI government has acknowledged that it is not possible to implement many of the Act's provisions at this time (Shatter, 2011). Key aspects of the Act still to be activated (as of November 2011) include the establishment of a formal register of charities and an agency to pursue charities for malpractice, together with the requirement for RoI charities to publish their accounts. While the RoI government and the sector's coordinating body (Irish Charities and Tax Research) have asked RoI charities to sign up to a voluntary code of practice that requires them to publish annual accounts and provide information to the public on how their money is being spent, initial acceptance by Irish charities appears very low (Irish Times, 2011; Shatter, 2011). For the RoI, in the continued absence of a specific charities regulator, the debate has centred on 
improving compliance and regulation rather than on improving reporting, ${ }^{5}$ with research often attempting to understand the state of the sector and fundraising rather than the standard of reporting (Donnelly-Cox and Cannon, 2010; Prizeman and McGee, 2009).

Globally, in 2006, the largest international non-governmental organisations (NGOs), several of which are also UK-registered charities, publicly endorsed an Accountability Charter, ${ }^{6}$ the purpose of which is to enhance organisational transparency and accountability, encourage communication with stakeholders, improve organisational performance and effectiveness, and define shared principles, policies and practices. In addition, the Global Reporting Initiative (2010) developed sustainability reporting guidelines for NGOs to encourage and aid members to discharge financial and procedural accountability.

\section{CHARITY GOVERNANCE, ACCOUNTING AND ACCOUNTABILITY}

While a range of studies on charity accounting, accountability and governance exists, some key thrusts of past research are considered here: areas that particularly interest the authors, and areas that have been the focus of much of their writing over many years. Research is broadly categorised into studies that have investigated the:

- Extent to which charity financial statements comply with the financial accounting recommendations of the extant SORP

- Disclosure patterns of information accompanying annual financial statements (often in the annual report)

- Extent and impact of stakeholder engagement with respect to reporting frameworks for charities

These categorisations are a convenient way to present the material, although many of the studies themselves impact across the three categories and more widely.

\section{Charity Financial Statements and the SORP}

Austin and Posnett (1979) and Bird and Morgan-Jones (1981)

Studies of UK charity reporting practice in the late 1970s identified widespread poor practice in reporting, and cast significant doubt on the usefulness of annual reports and financial statements as a means of providing accurate, reliable and comparable information to stakeholders (perhaps unsurprising given limited legislation, accounting standards and regulatory oversight in both the UK and the RoI). Austin and Posnett (1979) found that many UK charities were simply failing to provide information at all: in their survey of 393 large charities, only 25 per cent had up-to-date accounts filed with the Charity Commission, despite the requirement of the 1960 Charities Act to do so. Moreover, where accounts were supplied, quality, consistency and compliance with extant accounting standards were often not in evidence; Austin and Posnett (1979) cited examples of such non-standard practices 
as showing income net of costs (for example, fundraising costs) and significant variation in valuing and depreciating assets (including items such as buildings not valued at all).

In 1981, Bird and Morgan-Jones published a study of the annual reports and accounts of the top 100 UK fundraising charities (by income). Their study, which focused primarily on financial reporting, revealed a sector where non-compliance with accounting standards was prevalent, archaic accounting treatments were used and wide disparity in accounting practices between charities was observed. Examples of such practices included immediate expensing of fixed asset purchases (rather than capitalising and depreciating such assets over their useful life); recording legacy income (in full or partially) to capital rather than income; and, contrary to the rules on provisioning, creating provisions for future expenses which were charged to the income statement to reduce profit. This perceived bias towards treatments that made charities seem more in need of funds led Bird and Morgan-Jones (1981, p. 196) to opine that:

Management is fearful that, if they report truly and fairly, its fund raising activities will be adversely affected and therefore ways and means are found for tucking away revenue and charging expenses which would not be tolerated in business accounts.

Moreover, they concluded that this situation was tolerated and indeed perpetuated because there was 'no effective monitoring of the public accountability of charities by ensuring prompt filing of financial statements and by expert review of a significant proportion of these' (Bird and Morgan-Jones, 1981, p. 225).

These studies had exposed substantial poor reporting practice in a sector which was, even at that time, important in the context of the economy as a whole and highly visible in the public consciousness. In April 1982, in a stated response to Bird and Morgan-Jones' (1981) work, the Accounting Standards Committee set up a charities working party with representatives from various stakeholder groups (the accounting profession, charities, foundations and the Charity Commission) to look into ways of enhancing the usefulness and comparability of charities' annual reports. Following an extensive consultation period, it issued the first charity SORP (Accounting Standards Committee, 1988). Applying existing commercial standards to charities, in the majority of cases it clarified best practice (often close to the recommendations of Bird and Morgan-Jones, 1981).

Ashford (1989), Gambling, Jones, Kunz and Pendlebury (1990) and Hines and Jones (1992) Three very different studies completed shortly after the publication of the 1988 SORP concluded that that SORP had had very limited impact on the financial statements of the charities studied. Ashford (1989) investigated the compliance of the financial statements of large charities with the recommendations of the SORP, and highlighted that, notwithstanding some examples of good practice, many charities were continuing to use accounting practices contrary to the recommendations (and, it was suggested, the spirit) of the SORP. They did this, he argued, to present their position in a way which made those charities seem to be more in need of funds; examples included failing to recognise income from legacies in the income 
statement, and recording the value of investments at the (usually lower) cost value rather than market value.

In a study of six small charities, Gambling, Jones, Kunz and Pendlebury (1990) identified, through a series of semi-structured interviews, that not only were these smaller charities not applying the recommendations of the SORP, but that awareness of the existence of the SORP was low. In addition, the recommendations were seen as adding additional compliance costs with little or no perceived benefit to the charity. The authors suggested that this lack of awareness and perceived irrelevance, combined with the lack of resources then available to the Charity Commission to monitor or enforce compliance, made it unlikely that the SORP would impact significantly on the sector.

In a longitudinal study of the financial statements of large charities, Hines and Jones (1992) found that while the vast majority prepared the statements recommended by the SORP, dubious accounting practices in the preparation of those statements remained pervasive, citing such basic examples as failure to capitalise and depreciate assets. They argued that non-compliance with the mere recommendations of the SORP was unsurprising and opined that if this position was to change then legislation or mandating of the SORP would be required.

Williams and Palmer (1998) and Connolly and Hyndman (2000 and 2001)

The poor response of the sector to the 1988 SORP necessitated the development of a more rigid regulatory framework and strengthening of the SORP to ensure proper accountability in the sector. After further review and consultation, a revised SORP was published in 1995 (Charity Commission, 1995) ${ }^{7}$ and this recommended more standardised practices for financial reporting, rather than relying on the judgement of the preparing accountant, with the most radical change being the introduction of the Statement of Financial Activities (SOFA) in place of the income and expenditure statement. Following this, Williams and Palmer (1998), in a study reviewing the financial statements of a sample of small, medium-sized and large charities, identified some improvement in compliance with the 1995 SORP. They observed significant improvement among larger charities since the early 1980s, but fairly extensive failure to comply with the SORP's recommendations among small and medium-sized charities.

Connolly and Hyndman (2000) analysed the financial statements of the top 100 fundraising charities before and after the 1995 SORP revision. Referencing earlier studies including Bird and Morgan-Jones (1981), Ashford (1989), Hines and Jones (1992) and Williams and Palmer (1998), they commented that the 1988 SORP had had a significant, but lagged, impact over time on charity accounting practices. They argued that this delayed impact was as a result of a 'fairly gradual learning curve' (Connolly and Hyndman, 2000, p. 96) in the accounting profession on the recommendations of the SORP. However, in respect of the 1995 SORP only partial compliance was seen. Non-compliance was particularly observed in respect of some of the most significant changes, such as reporting on costs, and Connolly and Hyndman (2000) commented that given the 'radical' nature of the 1995 SORP changes and the lagged impact of earlier recommendations, change would perhaps again be seen, but it was likely to be later. Overall, they concluded that 'charity 
accounts have improved significantly since the early 1980s, where improvement is seen in terms of increasing compliance with recommended practice' (Connolly and Hyndman, 2000, p. 95).

In subsequent work exploring compliance with the SORP, and comparing Irish and British charities, Connolly and Hyndman (2001) found that Irish charities' compliance with the SORP was even more lagged and less complete. Suggesting reasons for these differences, they remarked that, compared to British charities, Irish charities (while also encouraged to apply the SORP) operated in a less regulated environment, with no legislative requirement on any charities to comply with the SORP and less scrutiny of their reporting.

\section{Disclosure Patterns of Information other than Financial Statements}

Over time the focus of much empirical work on UK and RoI charities has shifted away from financial accountability (usually framed in terms of compliance with the extant financial requirements of the SORP) to accountability for performance and the provision of additional background information valuable to the users of accounts. The potential importance of such information had been identified by Bird and Morgan-Jones (1981) but was not the focus of the 1988 SORP. However, progressively, over time, the performance and governance aspects of charities came more to the fore. Mirroring what was developing in the public sector at the time, a number of parties, including government, called for greater focus on performance measurement and performance reporting. For example, through the publication of Private Action, Public Benefit (Strategy Unit, 2002) the UK government highlighted the need for better performance information as a basis for building trust and confidence in the sector, and on supporting the sector in improving performance. As the SORP evolved, the performance and governance aspects were strengthened considerably. For example, from 1995 the SORP promoted reporting on the general progress of the charity and what it had been able to achieve during the year (supported by statistical information if available) and encouraged the provision of examples (such as the number of beneficiaries reached).

\section{Hyndman (1990 and 1991)}

Based upon an analysis of the annual reports of 163 large UK charities and a survey of 133 donors to such charities, Hyndman (1990) sought to identify the information that was routinely made available to donors through the annual report, and the most important information sought by donors to charities. In the study, donors were asked to rank fourteen types of financial and non-financial information, including frequently disclosed information, in terms of importance to them. This was compared with the information routinely made available to them in the annual report. He found that while audited financial statements dominated reporting by charities, donors viewed other information, particularly that relating to performance, as most important.

In a related study, Hyndman (1991) investigated whether the identified 'relevance gap' - the difference between the information disclosed by charities in their annual reports (mainly audited financial statement information) and the information required by donors (mainly performance-related information) - was due to a lack 
of awareness on the part of the providers of the information. The objectives of the paper were to identify the views of providers of information regarding the importance of donors as users of charity reports, and to ascertain the perceptions of such providers concerning the importance to donors of the fourteen information types used as the basis for previous study (Hyndman, 1990). Two key groups involved in the provision of information to donors (charity officials and auditors) were surveyed. As well as identifying the perceived importance of donors as users of charity annual reports (with both groups of providers overwhelmingly identifying donors as the user group to whom the annual report is primarily directed), the major part of each questionnaire asked charity officials and auditors to rate the fourteen information types in terms of perception of importance to donors. These perceptions were then compared with the actual importance to donors identified in the previous study. It was found that while providers of information are aware of the most important information required by donors (performance-related information), and donors are identified as the most important user of the annual report, the majority of charities do not disclose such information. Overall, the research discounted the possibility that the 'relevance gap' is caused by providers of information being unaware of the information needs of donors. Rather, it was argued that accountability to donors is not discharged in the most effective manner, with limited reporting of performance information to donors. In addition, it was suggested that there may be a general complacency among the providers of information with respect to the adequacy of existing reporting procedures, given that they know what is important but do not disclose, and limited motivation to improve accountability to donors.

Connolly and Hyndman (2003 and 2004)

In a study of the annual reports of large UK charities over two accounting periods, Connolly and Hyndman (2003), aware of the changes in the SORP and the pressure from various sources for charities to improve performance reporting, sought to identify the extent to which performance accountability was discharged. Annual reports were analysed using a checklist developed from the recommendations of the SORPs, the information types identified by Hyndman (1990) as being important to donors, and other sector guidance of the time (such as that by the Charities Aid Foundation, 2001). Categorising disclosures on this basis and comparing to the Hyndman (1990) study, they identified that many charities were providing extensive background information (for example, on how the charity was constituted, the mission and the need area addressed) and that there had been some limited improvement over time in performance reporting (such as reporting on goals, objectives and outputs). However, their primary conclusion was that, despite the recognised importance of performance information to the users of accounts, it was still not widely disclosed by charities.

A number of examples of charities' failings in this regard were given, including a significant proportion of charities failing to disclose a single measure of efficiency or effectiveness (two of the key criteria for judging performance). Reporting of efficiency and effectiveness measures actually decreased in the two periods studied, against an increase in the reporting of more 'marketing-focused' (Connolly and Hyndman, 2003, p. 117) information. The authors contrasted this situation with 
significant improvements in reporting in the UK public sector in the same time period, and suggested this deterioration might be due to a number of factors, including a lack of willingness and pressure to report in the charity sector, combined with a paucity of guidance on performance reporting in charities. They also suggested that the focus of the charity reporting debate on financial accounting matters 'may have detracted from a meaningful debate relating to the relevance of the information content of charity annual reports' (Connolly and Hyndman, 2003, p. 117).

Applying a similar methodology, and distinguishing between small and large charities, Connolly and Hyndman (2004) compared the reporting of performance information in British and Irish charities. Analogous to their findings in respect of financial reporting (Connolly and Hyndman, 2001), the authors identified that for almost all types of performance reporting, and across both size groups, Irish charities reported significantly less than their British counterparts. For example, measures of output were reported by 96 per cent of large British charities, 77 per cent of small British charities, 47 per cent of large Irish charities and 29 per cent of small Irish charities. Reasons for the lower disclosure by Irish charities were suggested as including the weaker legislative framework, little government focus on the issue, the relative lack of scrutiny and comparative lack of research into charity reporting practice in Ireland.

Connolly and Dhanani (2006)

Connolly and Dhanani (2006) investigated narrative reporting practices in the top 100 fundraising charities in the UK, including the disclosure of organisational information, financial management policies, financial information, operational information and non-financial performance information. They found that while charities readily disclosed organisational information and financial management policies, the quantity and quality of disclosure tended to decrease in the reporting of financial information, decreasing again in respect of operational information (including measures of fundraising efficiency) and lowest in respect of performance information. Performance reporting tended to be dominated by information on charitable activities (with 91 per cent of the sample reporting at least one measure), reporting on inputs (73 per cent), volunteer contributions (67 per cent) and outputs (66 per cent). Significantly lower levels of disclosure were seen in respect of reporting on results (17 per cent) or on effectiveness ( 3 per cent). Moreover, the authors commented that the charities tended to report using quantitative or monetary measures (depending on what was being reported), but that ratio analysis presentations were uncommon. Where the information was disclosed, a key concern in respect of this reporting was that:

Charities seldom provided disclosures of comparative information, explanations of results and plans for the future, indicating that there is considerable scope to improve reporting practices (Connolly and Dhanani, 2006, p. 59).

Dhanani (2009)

Dhanani (2009) reviewed the reporting practices of 73 of the largest charities reporting on the GuideStar UK website, and applied content analysis to those charities' 
records to identify the existence and quantity of reporting across four key disclosure types: charitable intent (or aims and objectives), charitable activities (or programmes), charitable performance (subdivided into outputs, results, efficiency and effectiveness) and future intentions (or plans/strategy). The study found that while all but one charity provided information on aims and objectives, and 89 per cent provided information on their activities, reporting on performance and future plans was much less common. She highlighted that while 75 per cent of charities provided some performance measures, these tended to be the 'lower order' measures such as simple quantifications of the services provided, rather than measures of efficiency or effectiveness. Additionally, only one-third of the sample provided any information on future plans, indicating 'a willingness to provide descriptive information but hold back information that organisations may be held to or questioned about' (Dhanani, 2009, p. 189). Dhanani (2009) argued that this lack of reporting was particularly concerning given the high levels of media attention and public scrutiny being focused on higher-order measures of performance, particularly on efficiency and effectiveness. While these results demonstrated some improvement in comparison with earlier studies (albeit acknowledging difficulties in that comparison), they also suggested wide variations in practice between the charities investigated. For example, fundraising charities were more likely to provide information on charitable activities, performance information and future plans (concurring with the findings of Connolly and Hyndman, 2003).

\section{Connolly and Dhanani (2009)}

Connolly and Dhanani (2009) carried out content analysis of the annual reports and annual reviews of the largest UK charities, an examination of their websites and a series of interviews with representatives of those charities. Their results identified continuing problems with the discharge of accountability in the sector - at the most basic level, 36 per cent of charities asked to supply a copy of their annual report failed to do so and therefore contravened a statutory requirement. Comparing their analysis with earlier research, they commented that the demonstration of accountability in the annual reports of charities had weakened over time. They contrasted the increasing length and perceived importance of these reports with lower disclosure levels of information relating to fiduciary accountability, financial managerial accountability and operational managerial accountability. Considering operational management disclosures in more detail, they found that reporting was dominated by information on the charity's activities, rather than on their performance or impact on society. They commented that:

Charities appear to seek legitimacy for their actions on the basis of the nature of their work (i.e. charitable activities and projects) rather than from evidence of the resulting societal change [or impact] (Connolly and Dhanani, 2009, p. 7).

From the interviews, conducted in tandem with their survey, the authors concluded that this was an identified problem among interviewees, who highlighted an information gap that existed both internally within charities in terms of how they assess their performance and externally in respect of their reporting of that performance. 
They acknowledged some attempts to report better on the impact of charity activities and recommended that such efforts be supported through attempts to put in place holistic and formal systems of performance measurement within charities.

\section{Engagement with Stakeholders}

Hyndman and McDonnell (2009)

In their 2009 paper, Hyndman and McDonnell provided a critical analysis of 'governance' in the context of charities, and examined both the theoretical underpinnings and empirical investigations relating to it. Their focus was very much a stakeholder focus, and the importance of stakeholder theory was highlighted in the paper. By exploring the major themes that form the basis of much of the discussion of governance in charities, primarily looking from the perspective of the key stakeholders in the sector, the paper presented a broad definition of governance with respect to charities and discussed governance issues in relation to important external stakeholders (donors, regulators and beneficiaries). In addition, key aspects of governance pertaining to internal charity stakeholders were considered in terms of two key themes: board composition and board roles, and the relationships between the board and staff/volunteers. The authors suggested that charity governance can be viewed as relating to the distribution of rights and responsibilities among and within the various stakeholder groups involved, including the way in which they are accountable to one another, and also relating to the performance of the organisation, in terms of setting objectives or goals and the means of attaining them. On the basis of this a research agenda for those interested in adding to knowledge in this area was outlined (albeit acknowledged as partial).

\section{Hyndman and McMahon (2010 and 2011)}

The objective of Hyndman and McMahon (2010) was to analyse the evolution of the UK charity SORP with insights from stakeholder theory. Stakeholder theory originated in the 1980s, the central argument advanced being that if organisations engaged with stakeholders on a basis of mutual trust and cooperation those organisations would build legitimacy and reputation that would give a competitive advantage over rivals. It was argued that for an accounting pronouncement such as a SORP, stakeholders might include groups or individuals who impact, or are impacted upon by, a sector's reporting regime. They opined that these considerations have been central in discussions on accounting principles both in the commercial and charitable sectors over many years. Drawing on work relating to stakeholder salience, they explored 'who or what really counts' (Mitchell, Agle and Wood, 1997, p. 853) when prioritising competing stakeholder claims as they impacted on the evolution of the SORP since the mid-1980s.

Analysing a period of almost twenty years, they contended that the SORP had developed from the 1988 version (which was truly 'recommended' rather than 'required', was heavily based on applying commercial accounting principles, was financial accounting focused, and allowed a high degree of preparer discretion) to a much more significant accounting and reporting document by the 2005 SORP (which is mandatory for many, applies charity-specific principles, requires significant amounts of governance and performance reporting, and allows only limited 
preparer discretion). Hyndman and McMahon (2010) argued that the language of stakeholder theory, with its emphasis on identification of key stakeholders, their salience and their information needs, was used by the Charity Commission and others as a foundation for discussions on appropriate accounting and accountability frameworks within the charity sector. From their analysis it was suggested the two most salient and continuing stakeholders in this process have been government and the accounting profession. Furthermore, in each case, it was argued that these stakeholder groups began as rather passive and inactive with respect to charity accounting and reporting issues, but, through time, as discussion built and awareness of the importance of the issues became clearer, they each engaged vigorously in shaping the SORP. Moreover, it was suggested that the perspectives of these two stakeholder groups had different focuses, with government being more concerned with performance and governance reporting, while the accounting profession's primary interest was more related to technical financial accounting issues.

This theme was extended in empirical work by Hyndman and McMahon (2011). Using insights from stakeholder theory and data from interviews with members of the various SORP committees, this research focused on the influence of one highly salient stakeholder - government - in developing a regime of quality accounting and reporting in the charity sector. It was argued that, over time, government as a stakeholder became much more vigorous and demonstrated considerable power and legitimacy as it has sought to push through agendas it perceived as urgent. In addition, the authors contended that government's influence has been partly coercive (in creating the regulatory framework, through legislation requiring SORP compliance, and as an increasingly important resource provider exercising a direct disciplining effect on those charities to whom it provides funds) and partly persuasive (in encouraging greater prominence to measuring and reporting performance, and in facilitating the basis for the drafting of best practice financial reporting). The authors claimed that the field data from the research suggested that government's increasing engagement over time with the charitable sector, often on the basis of a customer-provider relationship, has certainly influenced government's demands relating to the 'giving of accounts' to themselves (and more widely to other stakeholders) and is evidence of the powerful hand of government shaping accounting and reporting. Moreover, it was argued that much of this had to do with government's view with respect to the correct conduit through which certain services should be delivered to the public, and the increased prominence afforded the charity sector was evidence of it being viewed in a progressively more favourable light.

\section{RESEARCH AGENDA}

This paper has explored a range of issues relating to governance, accounting and accountability in charities, setting the discussion largely in a UK and RoI context. Moreover, while acknowledging that there are other issues that justify exploration, it presents past research relating to the extent to which charity financial statements comply with established accounting frameworks, disclosure patterns of information accompanying annual financial statements, and the extent and impact of 
stakeholder engagement with respect to reporting frameworks for charities. These are areas that particularly interest the authors, and areas that have been the focus of much of their writing over many years. On the basis of this, and on wider reflection as to the operation and importance of the charity sector in both the UK and RoI, a research agenda for those interested in adding to knowledge is now outlined in an attempt to excite academics who have not previously considered research in this area. Important themes that emerge in contemporary discussions of governance, accounting and accountability in the charity sector are the accountability of charities to their stakeholders, beneficiaries and beneficiary involvement, the regulation of the sector, volunteers and the impact of marketisation. These themes are reviewed separately below with components of a research agenda (expressed in the form of questions) at the end of each review.

\section{Accountability to Stakeholders}

Accountability (being the requirement to be answerable for one's conduct and responsibilities) is an important aspect of governance in charities. In considering accountability, two key questions emerge: to whom is a charity accountable and what form should that account take? While recognising the importance of a range of stakeholders (such as government, beneficiaries and the regulator), it has often been argued that donors (or funders) are the primary stakeholders to whom an account is owed: they provide funding to a charity and often receive no direct economic benefit in return. Without their support charities cannot function and charitable activity will cease. In terms of the form of the account, it is argued that while financial accountability (through high-quality, audited financial statements) is important (to indicate, for example, that the money raised has been used for the appropriate purposes, that the charity has 'lived within its means' and the level of resources available to the charity for future service provision), such accounts are likely only to be of secondary importance.

Wider information, particularly relating to performance, is probably paramount in discharging accountability to donors, and this will require the telling of 'the story' of the charity (often from the perspective of beneficiaries - if it is possible to operationalise such a perspective) in a way that is truthful, consequential and engages with donors. While donors generally have no right to withdraw their donation once made, they may not donate in the future if it appears that the charity used their donation inefficiently or ineffectively. In this sense, the relationship could be regarded as a principal-agent relationship, with a charity being accountable to its donors through the publication of information on its website, annual report, etc. It is noteworthy that the sector's own governance code in the UK (Governance Code Steering Group, 2010) extends 'accountability' more broadly that its commercial counterpart and includes, among other things, appropriate consultation on significant changes to the organisation's services or policies; listening and responding to the views of supporters, funders, beneficiaries, service users and others; and considering the organisation's responsibilities to the wider community.

A range of possible research questions therefore emerges. How is the accountability of charities discharged? Does it matter to donors and beneficiaries? What role, if any, can traditional formats like annual reports and annual reviews play in this? 
Are reporting frameworks like SORP important? If so, to whom? What consultation takes place (or should take place) with donors and beneficiaries regarding accountability? What effect does it have? Can charity reporting move beyond activity and output reporting, to reporting impact? Through what medium is accountability best discharged? In addition, do good governance guides, which have increasingly assumed greater prominence in the sector, help? Are the recommendations contained in such documents appropriate for all charities? What are the consequences of adherence to such guides? Does it result in improved performance, or is it merely a legitimising mechanism used in interactions with key external stakeholders?

\section{Beneficiaries and Beneficiary Involvement}

While donors may be viewed as the primary stakeholder for charities (although this is sometimes disputed), others have suggested that beneficiaries are equally (or even more) important. Often the mission of a charity is focused on the beneficiary, and those who work within a charity are often concerned with maximising the benefit provided to the beneficiary. An issue that arises is the extent to which beneficiaries are involved, or should be involved, in the decision-making functions of a charity (and consulted in terms of accountability mechanisms). Certainly the donor to a charity often takes a beneficiary-focused view of events (albeit this may be a somewhat removed view), because the plight of the beneficiary is frequently at the heart of the donation decision. However, it has been argued that involving beneficiaries can encourage a much sharper focus by a charity and guard against the danger of mission drift. Wellens and Jegers (2011) have hypothesised a positive correlation between the degree of involvement of beneficiaries in a charity and the performance of a charity. Indeed, over the last twenty years beneficiary (or user) involvement has been heralded as a necessarily good thing for charities and public sector organisations.

However, identifying beneficiaries and engaging with them in a meaningful way with respect to accounting and reporting issues (and in wider governance issues) is often problematical. This may be because of their motivation, capability and the urgency of their needs, and is especially difficult in certain types of charities (for example, those with animal welfare and medical research objectives). While engagement with such stakeholders has the potential to improve reporting and focus by charities considerably, and legitimise further the accounting and reporting framework, such engagement has, to date, been limited. At its very best, such engagement can, among other things, provide managers and members of boards with useful feedback on the effectiveness of service provision, cement a mutual vision that is shared by all stakeholders and be a source of important and appropriate ideas as to what should be planned for the future. However, possible adverse impacts of inappropriate beneficiary involvement can arise (such as tokenism, possible reduced performance of the charity and too much focus on current service recipients).

Therefore, from a research question perspective, does beneficiary involvement in decision making avoid mission drift? How can it be achieved? Are there adverse consequences? Can beneficiaries' views on accounting and accountability facilitate more appropriate accountability frameworks? 


\section{The Regulation of the Sector}

One argument is that government regulation of charities may be particularly apposite because of the large information asymmetry problems associated with the sector. For example, when a donor gives money to a charity, he or she will not have as much information as the people within the charity about the charity's intentions with regard to the use of the donation. Therefore, while this situation persists, donors will be unlikely to donate as much as they would if they had as much information about the use of their money as the charity, as they will be aware of the possibility of opportunism on the part of the charity workers (in the form of, for example, diversion of donated funds from the intended beneficiaries to themselves). Thus, a world in which this information asymmetry and potential for opportunism is reduced will be one in which the extent of charity donation is likely to increase as a donor will become more confident that his/her donation is going towards its intended purpose.

More (or better) regulation of the sector has the potential to, among other things, increase public confidence in charities (resulting in more public support for the sector), improve the management of charities (as they are aware of the possibility of investigation if their organisation is poorly run) and reduce the likelihood of scandal. Alternatively, it is possible that the intrinsic motivation of the large number of volunteers and staff involved may be 'crowded out' by excessive regulation, resulting in less volunteering and fewer skilled individuals wishing to work in a sector to which they are naturally committed and within which they are possibly prepared to accept a lower remuneration than if they worked in the business sector. Excessive and inappropriate regulation can thus undermine an important foundation of a good charitable sector.

Therefore, research questions relating to the appropriate balance between these contrasting factors can be asked: What is the effect of regulation upon charity performance? Should the level of regulation vary on the basis of charity size? What is viewed as 'excessive' in terms of regulation and in what ways do such regulations impact on individuals within a charity?

\section{Volunteers}

A major difference between charities and businesses is that charities often rely heavily on volunteers, either delivering the services of the charity or providing the administrative/governance backup that enables a charity to function (including acting as trustees). Volunteerism in the UK and RoI is extensive, both in charities and in other organisations (Cordery, Proctor-Thomson and Smith, 2011). For example, in England alone it is reckoned that 71 per cent of adults volunteer in some way each year and such volunteering contributes $£ 22.7$ billion to the UK economy (Volunteering England, 2011). The importance of such volunteerism has been highlighted by governments in many countries, for example in the 'Big Society', a flagship policy of the 2010 UK Conservative Party general election manifesto and an aspect of the Conservative-Liberal Democrat coalition government programme. Priorities relating to this include encouraging people to take active (particularly voluntary) roles in their communities, and supporting non-profit social action endeavours. A key idea is that volunteerism is critical to civil society and government must create 
the framework and environment to support this. Such volunteerism, which often brings with it a passion for the cause, can provide a counterbalance to pressures that can lead to mission drift in charities. In addition, it can be argued that the presence of volunteers, who especially in small local charities supply an important bond between charities and their communities, provides a vital link of accountability.

Given the above, how (if at all) are volunteers involved in the governance and accountability processes within charities? What impact does this have? How is accountability affected by their presence? How do (or should) charities account for the inputs that volunteers provide?

\section{The Impact of Marketisation}

The 'marketisation' of the charity sector, whereby charities are encouraged to adopt management approaches and values of the private sector, often in response to external influences, can create tensions (Bruce and Chew, 2011; Dacombe, 2011). With respect to governance issues, it is recognised by some (but perhaps not all) that charities are not businesses and therefore reading across and imposing private sector governance frameworks on the charity sector may not be appropriate, and indeed may be counterproductive (Hind, 2011). For example, should boards of trustees control managers and volunteers within a charity (as is often suggested by private sector governance frameworks), or should they partner managers and volunteers within a charity (as may be suggested by those who see individuals who work or volunteer in charities as naturally committed to the cause)? It could be argued that imposing private sector governance controlling and compelling norms in charities has the potential to undermine the charitable ethos and discourage volunteering.

It may even be the case that performance per se, as measured by terms like efficiency and effectiveness and often championed by those of a private sector managerial bent, may be significantly less important in charities than in businesses. This may be because involving volunteers brings major benefits to a charity (such as focus, passion and legitimation) that do not show up on any normal performance metric. In addition, while more (or better) regulation of the sector by government has the potential to, among other things, increase public confidence in charities (encouraging more public support for the sector), a danger is that excessive regulation can 'crowd out' the intrinsic motivation of volunteers and result in less volunteering by individuals who wish to engage with the sector. In the UK and RoI, accelerating marketisation can be detected (although possibly to varying degrees) with the increasing use of charities, often on a contractual basis, as a provider of public services (and the flow of public sector funds into the sector). As a consequence of this, pressure has been placed on charities to focus on particular priorities of government, operate in prescribed ways mandated by government and provide extensive financial and performance information required by government. A danger in this is that the core values of a charity could be undermined as money is 'chased', resulting in mission drift.

Given this, to what extent has such marketisation occurred in the charity sectors in the UK and RoI? What is its impact? Has mission drift occurred? To what extent, and in what ways, has government sought to influence what happens in the sector? Is this influence positive? 
Connolly, Hyndman and McConville

\section{CONCLUDING COMMENTS}

This paper has explored some key extant literature and research relating to governance, accounting and accountability in the charity sector. On the basis of this, a research agenda (or at least a set of research questions) for those interested in adding to knowledge in this area is outlined. It is understood that this is only partial, but hopefully it will provide encouragement to researchers to explore the important areas relating to governance, accounting and accountability in charities as a basis for improving understanding, evaluation and practice.

It is envisaged that this research agenda can be pursued using a mixture of qualitative and quantitative research techniques. Some of this research would involve engagement with the key stakeholders (for example regulators, support groups, charity managers, charity boards, volunteers and beneficiaries). Other aspects of it will involve quantitative analysis looking at forms of accountability and measures of effectiveness (if possible) and efficiency (albeit where much used indicators are often contested). In particular, the importance of financial accountability, as reflected in the production and use, if any, of best practice compliant financial statements, could be contrasted with performance accountability, as reflected in narrative statements contained in trustees' reports, relating to key non-financial performance indicators, possibly associated with the quantity and quality of service provision, and efficiency indicators. The availability, demand and use of such information within a charity (to aid decision making) and outside of a charity (with respect to external stakeholders) would provide insights to support the evaluation of accountability frameworks and planning and control systems.

If governance, accounting and accountability is poor in charities (and, as a consequence, scandals are more prevalent) publicity surrounding such occurrences could severely undermine confidence in the charity sector and reduce both charitable giving and charitable activity. Good accounting, accountability and governance processes are vital to support management decision making within charities and appropriate accountability by charities. Such may be desirable, or indeed necessary, for the continuing health and growth of the sector. Thus the continuing work of the SORP Committee, which sets accounting and reporting rules for charities, could be seen as important. This committee has, over time, facilitated the improvement in the quality of charity financial statements and the communication of wider performance and governance information to key stakeholders. Moreover, the ethos of charities, and the role that volunteers play in such organisations, must be considered when framing governance processes. If governments are genuinely concerned about supporting and expanding the roles of volunteers and charities in civil society then they should be aware that too much inappropriate regulation, and too much marketisation, increases the danger of undermining the ethos of the sector they wish to support (and has the potential to discourage volunteering).

In addition, while some lessons can be learned from both private sector and public sector models of governance, accounting and accountability, reading across should be undertaken cautiously. Given the motivation of many of those who involve themselves in charities, forms of governance that emphasise compelling and controlling (rather than partnering, encouraging and supporting) may 
be inappropriate. Finally, beneficiary involvement is increasingly accepted as an important aspect of good governance in charities. Where possible, creative ways of involving beneficiaries in the decision-making processes can prevent mission drift, provide useful feedback to management as they seek to improve performance and cement a mutual vision that is shared by all stakeholders. However, it must be realised that trying to achieve this in many charities is extremely difficult.

Overall, more research into what passes for good accounting, accountability and governance, and, as a result, greater debate of the issues, has the potential to support charities as they seek to relate to their communities and increase public confidence in what charities are doing. The net result of such research and such debate, if conducted with key stakeholder input and reflecting the context in which charities operate, can provide the basis for a better managed, more accountable and thriving charitable sector; this must surely be the desire of all those with a heart for the varied, valuable and socially desirable activities engaged in by charities.

\section{ENDNOTES}

1 The distinction between a not-for-profit organisation (NFPO), non-governmental organisation (NGO) and charity is often imprecise (Vakil, 1997; Martens, 2002). In broad terms, an NFPO (also referred to as a nonprofit organisation) is an organisation that does not distribute its surplus funds to owners or shareholders, but instead uses them to help pursue its goals. NFPOs include NGOs and charities. While most governments and their agencies meet the definition of an NFPO, they are usually considered a separate categorisation of organisation and not normally viewed as NFPOs. An NGO is a non-profit, voluntary group. NGOs perform a variety of services and humanitarian functions, bring citizens' concerns to governments, advocate and monitor policies and encourage political participation through the provision of information. A charity is an NFPO that meets stricter criteria regarding its purpose and the way in which it makes decisions and reports its finances.

2 Different political and legislative systems operate in England, Northern Ireland (NI), the RoI, Scotland and Wales. In this paper, the term 'United Kingdom' is used to refer to England, NI, Scotland and Wales; 'Britain' refers to England, Scotland and Wales; and 'Ireland' refers to NI and the RoI.

3 SORPs are recommendations on accounting practice for specialised industries or sectors, and they supplement other legal and regulatory requirements. The first charity SORP was issued in 1988, with subsequent revisions in 1995, 2000 and 2005.

4 The term 'annual report' here refers to documents which comprise organisations' annual financial statements as well as narrative reports by management.

5 It could be argued that exceptions to this include the Irish Nonprofits Knowledge Exchange (INKEx) project, creating a database of annual reports of Irish charities and the Statement of Guiding Principles for Fundraising promoted by Irish Charities Tax Research (2008), which includes guidelines on reporting.

6 See the International Non-Governmental Organisation Accountability Charter at <http://www.ingoaccount abilitycharter.org/>.

7 Changes in legislation in England and Wales (Charities Acts in 1992 and 1993 and Charity Accounting Regulations 1995, 2000 and 2005) and Scotland (Charity Accounts (Scotland) Regulations 2006) progressively made adherence to the SORP mandatory for larger charities.

\section{REFERENCES}

Accounting Standards Board (1999). Statement of Principles for Financial Reporting, London: Accounting Standards Board.

Accounting Standards Board (2007). Statement of Principles for Financial Reporting: Interpretation for Public Benefit Entities, London: Accounting Standards Board. 
Connolly, Hyndman and McConville

Accounting Standards Committee (1975). The Corporate Report, London: Accounting Standards Committee.

Accounting Standards Committee (1988). Accounting by Charities: Statement of Recommended Practice 2, London: Accounting Standards Committee.

American Accounting Association (1966). A Statement of Basic Accounting Theory, Evanston, IL: American Accounting Association.

American Institute of Certified Public Accountants (1973). Objectives of Financial Statements: Report of the Study Group on the Objectives of Financial Statements (Trueblood Report), New York, NY: American Institute of Certified Public Accountants.

Ashford, J.K. (1989). Charity Accounts, in L.C.L. Skerratt and D.J. Tonkins (eds.), Financial Reporting 1989-90: A Survey of UK Reporting Practice, London: Institute of Chartered Accountants in England and Wales.

Austin, M. and Posnett, J. (1979). The Charity Sector in England and Wales - Characteristics and Public Accountability, National Westminster Bank Quarterly Review, August, pp. 40-51.

Beattie, V., McInnes, B. and Fearnley, S. (2002). Through the Eyes of Management: A Study of Narrative Disclosures, Interim Report, London: Institute of Chartered Accountants in England and Wales.

Bird, P. and Morgan-Jones, P. (1981). Financial Reporting by Charities, London: Institute of Chartered Accountants in England and Wales.

Blagescu, M., Lloyd, R., Dombrowski, K., Kadosh, R. and Oatham, J. (2006). Global Accountability Report, London: One World Trust.

Boyne, G. and Law, J. (1991). Accountability and Local Authority Annual Reports: The Case of Welsh District Councils, Financial Accountability \& Management, Vol. 7, No. 4, pp. 179-194.

Breen, O., Ford, P. and Morgan, G. (2009). Cross-Border Issues in the Regulation of Charities: Experiences from the UK and Ireland, International Journal of Not-for-Profit Law, Vol. 11, No. 3, pp. 5-41.

Brody, E. (2002). Accountability and Public Trust, in A. Saloman (ed.), The State of America's Non-Profit Sector, Washington, DC: Brookings Institution Press.

Brown, L.D. and Moore, M. (2001). Accountability, Strategy, and International Nongovernmental Organizations, Nonprofit and Voluntary Sector Quarterly, Vol. 30, No. 3, pp. 569-587.

Bruce, I. and Chew, C. (2011). The Marketisation of the Voluntary Sector: Implications for Charities' Distinctiveness and Values, Public Money \& Management, Vol. 31, No. 3, pp. 155-156.

Cabinet Office of the Third Sector (2009). Key Facts on the Third Sector, July, London: Cabinet Office of the Third Sector, available from: <http://webarchive.nationalarchives. gov.uk/+/http://www.cabinetoffice.gov.uk/media/231495/factoids.pdf>, accessed 12 October 2011.

Cadbury Report (1992). The Financial Aspects of Corporate Governance, London: Gee.

Campbell, D., Moore, G. and Shrives, P. (2006). Cross-Sectional Effects in Community Disclosure, Accounting, Auditing and Accountability Journal, Vol. 19, No. 1, pp. 96-114.

Canadian Institute of Chartered Accountants (1980). Financial Reporting for Non-Profit Organisations (A Research Study), Toronto: Canadian Institute of Chartered Accountants.

Charities Aid Foundation (2001). Tell the Main Story: Guidance on Effective Annual Reporting, London: Charities Aid Foundation.

Charity Commission (1995). Accounting by Charities: Statement of Recommended Practice, London: Charity Commission.

Charity Commission (2000). Accounting and Reporting by Charities: Statement of Recommended Practice, London: Charity Commission.

Charity Commission (2004). Annual Report 2004, London: Charity Commission. 
Charity Commission (2005). Accounting and Reporting by Charities: Statement of Recommended Practice, London: Charity Commission.

Charity Commission (2011). Facts and Figures, London: Charity Commission, available from:

<http://www.charitycommission.gov.uk/About_us/About_charities/factfigures.aspx>, accessed 12 October 2011.

Charity Commission for Northern Ireland (2011). List of Charities in Northern Ireland 2011, Belfast: Charity Commission for Northern Ireland.

Charity Finance Directors' Group (2003). Inputs Matter: Improving the Quality of Reporting in the Charity Sector, London: Charity Finance Directors' Group.

Connolly, C. and Dhanani, A. (2006). Accounting Narratives: The Reporting Practices of British Charities, Journal for Public and Nonprofit Services, Vol. 35, No. 1, pp. 39-62.

Connolly, C. and Dhanani, A. (2009). Research Report 109: Narrative Reporting by UK Charities, London: Association of Chartered Certified Accountants.

Connolly, C. and Hyndman, N. (2000). Charity Accounting: An Empirical Analysis of the Impact of Recent Changes, British Accounting Review, Vol. 32, No. 1, pp. 77-100.

Connolly, C. and Hyndman, N. (2001). A Comparative Study on the Impact of Revised SORP 2 on British and Irish Charities, Financial Accountability \& Management, Vol. 17, No. 1, pp. 73-97.

Connolly, C. and Hyndman, N. (2003). Performance Reporting by UK Charities: Approaches, Difficulties and Current Practice, Edinburgh: Institute of Chartered Accountants of Scotland.

Connolly, C. and Hyndman, N. (2004). Performance Reporting: A Comparative Study of British and Irish Charities, British Accounting Review, Vol. 36, No. 2, pp. 127-154.

Cordery, C.J., Proctor-Thomson, S. and Smith, K.A. (2011). Valuing Volunteer Contributions to Charities, Public Money \& Management, Vol. 31, No. 3, pp. 193-200.

Coy, D., Fischer, M. and Gordon, T. (2001). Public Accountability: A New Paradigm for College and University Annual Reports, Critical Perspectives in Accounting, Vol. 12, No. 1, pp. $1-31$.

Dacombe, R. (2011). Can We Argue Against It? Performance Management and State Funding of Voluntary Organisations in the UK, Public Money \& Management, Vol. 31, No. 3, pp. $159-166$.

Davison, J. (2007). Photographs and Accountability: Cracking the Codes of an NGO, Accounting, Auditing and Accountability Journal, Vol. 20, No. 1, pp. 133-158.

Deegan, C. (2002). The Legitimising Effect of Social and Environmental Disclosures: A Theoretical Foundation, Accounting, Auditing and Accountability Journal, Vol. 1, No. 3, pp. 282-311.

Dhanani, A. (2009). Accountability of UK Charities, Public Money \& Management, Vol. 29, No. 3, pp. 183-190.

Donnelly-Cox, G. and Cannon, S.M. (2010). Responses of Non-Profit Organisations to Altered Conditions of Support: The Shifting Irish Landscape, Voluntary Sector Review, Vol. 1, No. 2, pp. 335-353.

Donoghue, F., O'Regan, A., McGee, S. and Donovan, A.M. (2007). Exploring the Irish Fundraising Landscape: A Report on the Practice and Scale of Charitable Fundraising from the Public in Ireland, Dublin: Irish Charities Tax Research Ltd and the Centre for Nonprofit Management, School of Business, University of Dublin, Trinity College.

Ebrahim, A. (2003). Making Sense of Accountability: Conceptual Perspectives for Northern and Southern Nonprofits, Nonprofit Management and Leadership, Vol. 14, No. 2, pp. 191-212.

Edwards, M. and Hulme, D. (1995). Non-Governmental Organisations: Performance and Accountability (Beyond the Magic Bullet), London: Earthscan Publications. 
Connolly, Hyndman and McConville

Ezzamel, M., Robson, K., Stapleton, P. and McLean, C. (2007). Discourse and Institutional Change: 'Giving Accounts' and Accountability, Management Accounting Research, Vol. 18, No. 2, pp. 150-171.

Financial Accounting Standards Board (1980). SFAC No. 4 Objectives of Financial Reporting by Non-Business Organizations, Norwalk, CT: Financial Accounting Standards Board.

Gambling, T., Jones, R., Kunz, C. and Pendlebury, M. (1990). Accounting by Charities: The Application of SORP 2: Certified Research Report No. 21, London: Association of Chartered Certified Accountants.

Geer, B., Maher, J. and Cole, M. (2008). Managing Nonprofit Organizations: The Importance of Transformational Leadership and Commitment to Operating Standards for Nonprofit Accountability, Public Performance and Management Review, Vol. 32, No. 1, pp. 51-75.

Global Reporting Initiative (2010). Sustainability Reporting Guidelines \& NGO Sector Supplement, Amsterdam: Global Reporting Initiative.

Goodin, R. (2003). Democratic Accountability: The Distinctiveness of the Third Sector, European Journal of Sociology, Vol. 44, No. 3, pp. 359-371.

Governance Code Steering Group (2010). Good Governance: A Code for the Voluntary and Community Sector, second edition, London: Governance Code Steering Group, available from: <http:/ / www.goodgovernancecode.org.uk/files/Code $\% 20$ of $\% 20$ Governance $\% 20$ second \%20edition\%20v1.0\%20Final\%20Full\%20page.pdf>, accessed 12 October 2011.

Government Accounting Standards Board (1987). Concepts Statement No. 1: Objectives of Financial Reporting, Stamford, CT: Government Accounting Standards Board.

Gray, R., Bebbington, J. and Collison, D. (2006). NGOs, Civil Society and Accountability: Making the People Accountable to Capital, Accounting, Auditing and Accountability Journal, Vol. 19, No. 3, pp. 319-348.

Gray, R., Kouhy, R. and Lavers, S. (1995). Corporate Social and Environmental Reporting: A Review of the Literature and a Longitudinal Study of UK Disclosure, Accounting, Auditing and Accountability Journal, Vol. 8, No. 2, pp. 47-77.

Hind, A. (2011). Increasing Public Trust and Confidence in Charities: On the Side of the Angels, Public Money \& Management, Vol. 31, No. 3, pp. 201-206.

Hines, A. and Jones, M.J. (1992). The Impact of SORP on the UK Charitable Sector: An Empirical Study, Financial Accountability \& Management, Vol. 8, No. 1, pp. 49-67.

Home Office (2003). Charities and Not for Profits: A Modern Legal Framework - The Government's Response to 'Private Action, Public Benefit', London: Home Office.

Hyndman, N. (1990). Charity Accounting: An Empirical Study of the Information Needs of Contributors to UK Fundraising Charities, Financial Accountability \& Management, Vol. 6, No. 4, pp. 295-307.

Hyndman, N. (1991). Contributors to Charities - A Comparison of their Information Needs and the Perceptions of Such by the Providers of Information, Financial Accountability $\mathcal{E}$ Management, Vol. 7, No. 2, pp. 69-82.

Hyndman, N. and Anderson, R. (1995). The Use of Performance Information in External Reporting: An Empirical Study of UK Executive Agencies, Financial Accountability \& Management, Vol. 11, No. 1, pp. 1-17.

Hyndman, N. and McDonnell, P. (2009). Governance and Charities: An Exploration of Key Themes and the Development of a Research Agenda, Financial Accountability \& Management, Vol. 25, No. 1, pp. 5-31.

Hyndman, N. and McMahon, D. (2010). The Evolution of the UK Charity Statement of Recommended Practice: The Influence of Key Stakeholders, European Management Journal, Vol. 28, No. 6, pp. 255-266. 
Hyndman, N. and McMahon, D. (2011). The Hand of Government in Shaping Accounting and Reporting in the UK Charity Sector, Public Money E Management, Vol. 31, No. 3, pp. 167-174.

Institute of Fundraising (2006). Codes of Fundraising Practice, London: Institute of Fundraising, available at: <http://www.institute-of-fundraising.org.uk/guidance/codes-of-fundraisingpractice/>, accessed 12 October 2011.

Irish Charities Tax Research (2008). Statement of Guiding Principles for Fundraising, Dublin: Irish Charities Tax Research, available from: <http://www.ictr.ie/content/fundraisingcodes-practice>, accessed 12 October 2011.

Irish Times (2011). Regulating Charities, Irish Times, 15 March, available from: <http:/ /www. irishtimes.com/newspaper/opinion/2011/0315/1224292159741.html>, accessed 12 October 2011.

Jackson, P.M. (1982). The Political Economy of Bureaucracy, London: Philip Allan.

Jones, R. and Pendlebury, M. (2010). Public Sector Accounting, Vol. 6, London: FT Prentice Hall.

Laughlin, R. (1990). A Model of Financial Accountability and the Church of England, Financial Accountability \& Management, Vol. 6, No. 2, pp. 93-114.

Macve, R. (1981). A Conceptual Framework for Financial Accounting and Reporting: The Possibilities for an Agreed Structure, London: Institute of Chartered Accountants in England and Wales.

Mäkelä, H. and Näsi, S. (2010). Social Responsibilities of MNCs in Downsizing Operations: A Finnish Forest Sector Case Analyzed from the Stakeholder, Social Contract and Legitimacy Theory Point of View, Accounting, Auditing and Accountability Journal, Vol. 23, No. 2, pp. 149-174.

Martens, K. (2002). Mission Impossible? Defining Nongovernmental Organisations, Voluntas: International Journal of Voluntary and Nonprofit Organizations, Vol. 13, No. 3, pp. 271-285.

Mitchell, R.K., Agle, B.R. and Wood, D.J. (1997). Toward a Theory of Stakeholder Identification and Salience: Defining the Principle of Who and What Really Counts, Academy of Management Review, Vol. 22, pp. 853-886.

Munro, R. and Mouritsen, J. (1996). Accountability: Power, Ethos and the Technologies of Managing, London: International Thompson Publishing.

National Council for Voluntary Organisations (2005). UK Giving 2004/05, London: National Council for Voluntary Organisations.

National Council for Voluntary Organisations and Charities Aid Foundation (2010), UK Giving 2010: An Overview of Charitable Giving in the UK 2009/10, London: National Council for Voluntary Organisations/Charities Aid Foundation, available from: <https:/ /www. cafonline.org/pdf/UK\%20Giving\%202010_101210.pdf>, accessed 12 October 2011.

Northern Ireland Council for Voluntary Action (2009). The State of the Sector V - Northern Ireland Voluntary and Community Sector Almanac 2009, Belfast: Northern Ireland Council for Voluntary Action.

O'Dwyer, B. (2005). The Construction of a Social Account: A Case Study in an Overseas Aid Agency, Accounting, Organizations and Society, Vol. 30, No. 3, pp. 279-296.

O'Dwyer, B. and Unerman, J. (2007). From Functional to Social Accountability: Transforming the Accountability Relationship between Funders and Non-Governmental Development Organisations, Accounting, Auditing and Accountability Journal, Vol. 20, No. 3, pp. 446-471.

Office of the Scottish Charity Regulator (2011). Scottish Charities 2011, Dundee: Office of the Scottish Charity Regulator. 
Connolly, Hyndman and McConville

Panozzo, F. (1996). Accountability and Identity: Accounting and the Democratic Organization, in R. Munro and J. Mouritsen (eds.), Accountability: Power, Ethos and the Technologies of Managing, London: International Thompson Publishing.

Patton, J.M. (1992). Accountability and Governmental Financial Reporting, Financial Accountability \& Management, Vol. 8, No. 3, pp. 165-180.

Prizeman, G. and McGee, S. (2009). Charitable Fundraising in an Economic Downturn: The First Annual Report on Income and Fundraising Activity in Irish Charities, Dublin: Centre for Nonprofit Management and Irish Charities Tax Research Ltd.

Roberts, J. (1991). The Possibilities of Accountability, Accounting, Organizations and Society, Vol. 16, No. 4, pp. 355-368.

Rutherford, B.A. (1983). Financial Reporting in the Public Sector, London: Butterworths.

Samkin, G. and Schneider, A. (2010). Accountability, Narrative Reporting and Legitimation: The Case of a New Zealand Public Benefit Entity, Accounting, Auditing and Accountability Journal, Vol. 23, No. 2, pp. 256-289.

Shatter, A. (2011). Address by the Minister for Justice, Equality and Defence to the Irish Charities and Tax Research Annual Conference, 10 November, available from: <www.justice. ie/en/JELR/Pages/SP11000216>, accessed 12 October 2011.

Sinclair, A. (1995). The Chameleon of Accountability: Forms and Discourses, Accounting, Organizations and Society, Vol. 20, Nos. 2-3, pp. 219-237.

Slim, H. (2002). By What Authority: The Legitimacy and Accountability of Non-Governmental Organisations, Journal of Humanitarian Assistance, available from: <http://www.gdrc. org/ngo/accountability/by-what-authority.html>, accessed 12 October 2011.

Strategy Unit (2002). Private Action, Public Benefit: A Review of Charities and the Wider Not-forProfit Sector, London: Cabinet Office.

Taylor, N.V. (1989). Local Authority Accounting: The Development of a Conceptual Framework, Financial Accountability \& Management, Vol. 5, No. 1, pp. 19-38.

Taylor, D. and Rosair, M. (2000). Effects of Participating Parties, the Public and Size on Government Departments' Accountability Disclosure in Annual Reports, Accounting, Accountability and Performance, Vol. 6, No. 1, pp. 77-98.

Tilling, M. and Tilt, C. (2010). The Edge of Legitimacy: Voluntary Social and Environmental Reporting in Rothmans' 1956-1999 Annual Reports, Accounting, Auditing and Accountability Journal, Vol. 23, No. 1, pp. 55-81.

Vakil, A.C. (1997). Confronting the Classification Problem: A Taxonomy of NGOs, World Development, Vol. 25, No. 12, pp. 2057-2070.

Volunteering England (2011). Key Volunteering Facts and Figures for England, Volunteering England, available from: <http://www.volunteering.org.uk/component/content/ article/7-media-centre/721-key-volunteering-facts-and-figures $>$, accessed 12 October 2011.

Walker, C., Pharoah, C., Jas, P., Paasey, A. and Romney-Alexander, D. (2002). A Lot of Give: Trends in Charitable Giving in the 21st Century, London: Charities Aid Foundation.

Wellens, L. and Jegers, M. (2011). Beneficiaries' Participation in Nonprofit Organisations: A Theory-Based Approach, Public Money \& Management, Vol. 31, No. 3, pp. 175-182.

Williams, S. and Palmer, P. (1998). The State of Charity Accounting: Developments, Improvements and Continuing Problems, Financial Accountability \& Management, Vol. 14, No. 4, pp. 265-279. 